\title{
Effect of Partial Replacement of Fishmeal with Duck Weed (Lemna minor) Feed On the Growth Performance of Cyprinus carpio Fry
}

\author{
Sashi Bhushan Mohapatra ${ }^{1}$ and A.K.Patra ${ }^{2}$ \\ ${ }^{1}$.Department of Zoology, Banki Autonomous College, Banki,Cuttack,Odisha,India-754008. \\ 2.P.G. Department of Zoology, Utkal University, Vani Vihar, Bhubaneswar, Odisha,India-751004.
}

\begin{abstract}
The acceptable nutritional value of Lemna as an ingredient in diets for Cyprinus carpio (L.) fry was experimented under aquarium culture system for 120 days. For that purpose fry of approximately equal weight were distributed in groups of 15 to each four aquaria at $0 \%, 15 \%, 30 \%$ and $45 \%$ inclusion levels of Lemna. The fry were fed at 5\% body weight twice daily morning and evening. The three inclusion levels of duckweed supported the growth of Cyprinus carpio fry but growth performance, weight gain growth rate was favoured by low inclusion of duckweed meal. Highest bodyweight gain \% was recorded on the group of fish bed diet $(0 \%$ inclusion of duckweed) which was not significantly different $(P<0.05)$ from $(15 \%$ level inclusion of duckweed). The study clearly showed that fry fed diet 15\% duckweed dietary inclusion perform best result and fishmeal was non replaceable but can be supplemented with duckweed up to an optimum level to produce cost effective feed.
\end{abstract}

Key words: Duck weed, Feed ingredients, growth performance

\section{Introduction}

The success of commercial aquaculture operations depends mainly on one key biological component that is the availability of suitable diets which provide required nutrients for optimum growth. As a result, use of supplementary feed has become inevitable for the carrying capacity of culture systems and can enhance fish production by many folds [1]. One important aspect in common carp farming is to identify economically viable and easily available ingredients for formulating diets that are nutritive palatable and having maximal conversion ratio to give greater fish yield per application. Feed conversion ratio (FCR) values of various fish feeding ingredients for carps under controlled conditions have been estimated by many workers $[2,3,4,5]$.

The artificial feed for the growth of common carp depends upon the local environment, culture method, stocking density, quality and quantity of feed supplied. Common carp is an omnivorous fish and can eat any digestible feed item. It eats artificial protein rich food stuffs such as fish meal, blood meal, caracass meal, dried insects, silkworm pupae, flesh of molluscs minced flesh of fish, frog and snake [6]. In fact significant effort has been directed towards evaluating the nutritive value of different non-conventional feed resources including terrestrial and aquatic macrophytes to formulate nutritionally balanced and cost effective diet for fish and poultry $[7,8,9,10]$.

Studies on growth performance of cultured fry of common carp in relation to feeding provide information for successful application in the management and exploitation of resources. The present trial was undertaken to quantitatively analyze the comparative efficacy of different formulated feeds of plant and animal origin in relation to growth of fry of Cyprinus carpio. The feeds selected for this investigation are fish meal of animal origin and duckweed (Lemna minor) meal of plant origin. Duckweed meal has been known for its high nutritive value with as much as $40 \%$ and above crude protein depending on the culture system[11,12,13,14,15].

The present study was conducted to assess the suitability or otherwise of duckweed meal as a partial replacement for the artificial meal in the diet of Cyprinus carpio fry.

\section{Experimental fish}

\section{Materials And Methods}

The common carp, Cyprinous carpio (L.) (1758) has been one of the oldest cultured species of fish for food. It was selected for the present experiment. The rationale of its selection was that it has excellent growth rate, easy availability wide distribution, commercial importance etc. it is a hardy fish for better survival. Its seed has been high demand by the aqua-farmers for variety of purposes such as mono-culture and poly culture. In view of consistent demand for fry and fingerlings, studies were therefore undertaken in aquaria and ponds.

Fry of Cyprinus carpio were collected from Government fish feed hatchery. The fry were kept in the glass aquaria and acclimatized for 15 days on the feed supplement containing rice bran and Groundnut oil cake (GNOC) in order to habituate them for artificial feeding. Thereafter, during experimental period of 120 days, the fishes were fed with the formulated experimental diets @ $5 \%$ of body weight/day. The weight of fry were 
measured after every 15 days and based on the increase in body weight of fry and their ration was readjusted @ $5 \%$ of their body weight twice daily.

\section{Experimental diets}

In this present study, an attempt was made to utilize the aquatic weeds and trash fish for feed preparation. The ingredients, i.e. rice bran, GNOC, soybean, fish meal and Lemna were procured from local area and were dried and grinded to powder form. Four dry diets were prepared in which fish meal was replaced with weeds at $0 \%, 15 \%, 30 \%$, and $45 \%$ levels. The diets were fortified with vitamins and salt.

\section{Experimental procedure}

The experiment was run in 12 glass aquaria in triplicate for each dietary treatment. The working

dimension of each aquarium was $60 \times 40 \times 45 \mathrm{~cm}^{3}$. A total of 450 nos. of Cyprinus carpio fry of average $1.61 \pm$ $0.21 \mathrm{~g}$ body weight were distributed in to 30 groups of 15 fish each group. The study was conducted for 120 days. The water quality parameters, temperature, $\mathrm{pH}$, DO were analyzed through the methods outlined by APHA (1985) [16] and monitored daily. Water samples from all the aquaria also taken on fortnightly basis to see the changes in physicochemical factors and their average values were calculated on monthly basis.

\section{Statistical analysis:}

Statistical analysis of data was performed by analysis of variance (ANOVA) using Microsoft Software statistic followed by Duncan's multiple range test [17].

Table: 1 Percentage composition of experimental feed of Lemna

\begin{tabular}{|l|c|c|c|c|}
\hline \multirow{2}{*}{ Ingredients } & \multicolumn{3}{|c|}{ Percentage inclusion of Lemna } \\
\cline { 2 - 5 } & $0 \%$ & $15 \%$ & $30 \%$ & $45 \%$ \\
\hline Lemna & 0 & 3.9 & 7.8 & 11.7 \\
\hline Fish meal & 26.5 & 22.6 & 18.7 & 14.8 \\
\hline Soybean & 20.0 & 20.0 & 20.0 & 20.0 \\
\hline Groundnut oil cake (GNOC) & 30.0 & 30.0 & 30.0 & 30.0 \\
\hline Rice bran & 22.0 & 22.0 & 22.0 & 22.0 \\
\hline Vitamin & 1.0 & 1.0 & 1.0 & 1.0 \\
\hline Salt & 0.5 & 0.5 & 0.5 & 0.5 \\
\hline Total & 100.0 & 100.0 & 100.0 & 100.0 \\
\hline
\end{tabular}

Table: 2 Proximate Composition of Experimental feed of Lemna

\begin{tabular}{|l|l|l|l|l|l|}
\hline Lemna feed & $\%$ crude protein & \% crude lipid & $\%$ Ash & \% Moisture & \% crude fiber \\
\hline $0 \%$ & 40.12 & 8.5 & 13.0 & 2.2 & 4.9 \\
\hline $15 \%$ & 38.60 & 6.8 & 12.2 & 1.4 & 4.5 \\
\hline $30 \%$ & 36.54 & 6.4 & 11.0 & 1.3 & 4.8 \\
\hline $45 \%$ & 35.82 & 6.0 & 10.3 & 1.6 & 5.2 \\
\hline
\end{tabular}

\section{Results And Discussion}

Feeds from plant origin have an excellent amino acid profile been reported to be effective and less expensive ingredients for formulation of fish diets [18]. In the past few decades, feeds from plant origin have been accepted for Indian major carps because the growth observed in these fish has been reported to be as good as that obtained with the traditional feed. In tropical developing countries, where algal production rates are high, algae have been receiving increasing attention as an alternate protein possessing relatively high protein content (50-65\%), which may be included in balanced fish feeds [19].

Incorporation of Lemna feed (commonly known as duckweed meal) to replace the fish meal in formulated fish feed can be attributed to achieve the goal of formation of cost-effective fish feed. The three inclusion level of duckweed is experimental feed supported the growth for Cyprinus carpio (L.). However, growth performance was favoured by optimum inclusion level of duckweed meal in the experimental feed. In the present study, the experimental diets of Lemna meals are represented in Table-1. The ingredients of experimental diet include Lemna, Fishmeal, Soybean, Groundnut oil cake, Rice bran, Vitamin, and Salt at different proportions of Lemna meal. The proximate composition of the Lemna feeds are recorded in Table-2.

The fish meal was replaced by $0 \%, 15 \%, 30 \%$, and $45 \%$ Lemna feed. The highest percentage of crude protein $(40.12 \%)$ was recorded at $0 \%$ replacement of Lemna feed and the least $(35.82 \%)$ was at $45 \%$ replacement.

Data on growth performance, weight gain, growth rate and survival rate are presented in Table-3. A decreasing trend in growth performance was noticed with increasing level of Lemna feed from $15 \%$ to $45 \%$ replacement. It has also been observed that the growth performance of common carp in $0 \%$ replacement was 
more than the $15 \%$ replacement of Lemna feed so far as the protein content in respective replacement was concerned. No doubt, animal protein is essential for the growth of carp, plant protein has no less importance for the same cause. Probably, due to that reason, the Lemna feed at $15 \%$ replacement has shown significantly higher $(\mathrm{P}<0.05)$ impact than the other three treatments on the growth performance of the common carp (Figure 1).

Highest body weight gain \% was recorded on the group of fish fed diet $(0 \%$ level of inclusion of Lemna) which was not significantly different $(\mathrm{P}<0.05)$ from the $(15 \%$ level of inclusion of Lemna) (Figure 2).The percentage of survival rate was highest in $0 \%$ and lowest in $30 \%$ Lemna replacement fish meal.

The intensification of fish culture has led to dependence on artificial feeds. Protein is the most expensive component in fish feeds and also the most important factor affecting growth performance of fish and feed cost [20]. Reducing the feeding costs could be a key factor for the successful development of aquaculture. Fish have high dietary protein requirement [21]. The significance of qualitative and quantitative feeds is well recognized [22] and the level of dietary protein is of fundamental importance, because it significantly influences growth, survival and yield of fish. Therefore, considerable research effort is needed to determine the quantity and quality of dietary protein necessary to achieve optimum growth performance of fish.

To formulate a low cost feed, ingredients from plant and animal sources are used to fulfill the protein requirement of the fish meal, fully or partially. The inter-relationship between the dietary energy requirement and the growth of fish and the importance of proper protein nutrition has been well established. So, fish nutritionists pay greater attention to reduce the cost of artificial diets by introducing alternative protein sources

Table 3: Growth performance of common carp fry fed Lemna meal based feed for 120 days $( \pm \mathrm{SE})$

\begin{tabular}{|l|l|l|l|l|}
\hline Parameters & \multicolumn{1}{|c|}{$0 \%$} & $15 \%$ & $30 \%$ & \multicolumn{1}{|c|}{$45 \%$} \\
\hline Initial weight (g) & $1.72 \pm 0.21$ & $1.62 \pm 0.19$ & $1.60 \pm 0.18$ & $1.51 \pm 0.17$ \\
\hline Final wt (g) & $14.22 \pm 0.72$ & $13.47 \pm 0.68$ & $12.84 \pm 0.63$ & $11.23 \pm 0.54$ \\
\hline Total wt gain (g) & $12.50 \pm 0.62$ & $11.85 \pm 0.57$ & $11.24 \pm 0.53$ & $9.72 \pm 0.49$ \\
\hline Body wt gain \% & $726.74 \pm 3.86$ & $731.48 \pm 3.88$ & $702.50 \pm 3.53$ & $643.70 \pm 2.91$ \\
\hline Growth rate(g/day) & $0.104 \pm 0.02$ & $0.098 \pm 0.02$ & $0.093 \pm 0.02$ & $0.081 \pm 0.03$ \\
\hline \% of survival & \multicolumn{1}{|c|}{87} & 80 & 67 & 73 \\
\hline
\end{tabular}

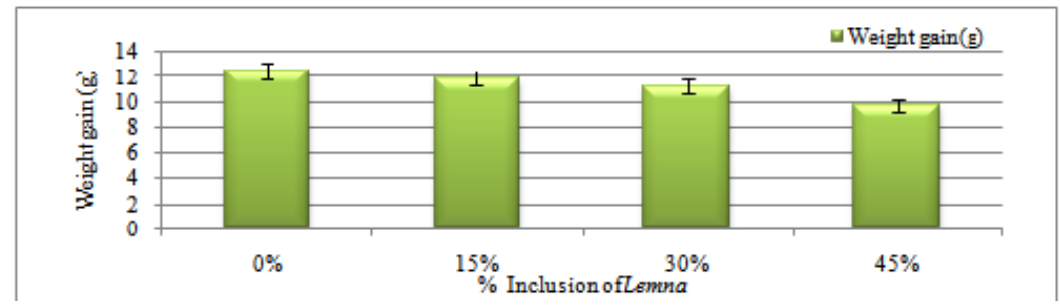

Figure 1 Total weight gain $(\mathrm{g})$ of carp fry fed with $\%$ inclusion of Lemna meal based feed $( \pm \mathrm{SE})$.

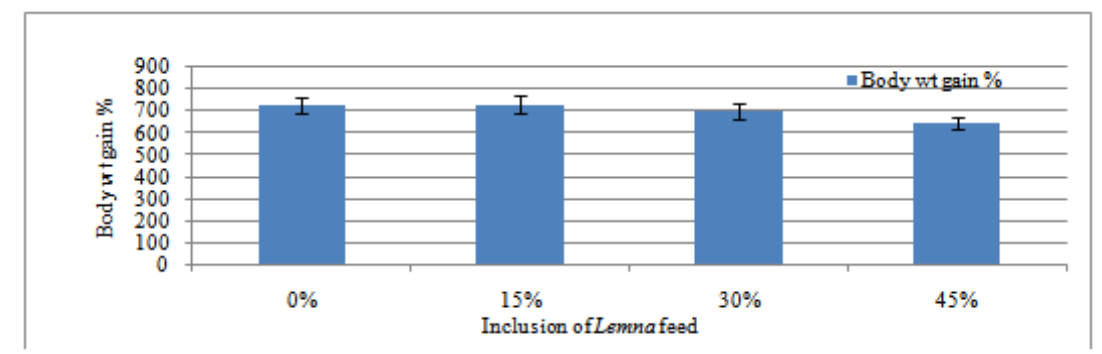

Figure 2 Body weight gain \% ( $\pm \mathrm{SE})$ of Cyprinus carpio fry fed with Lemna meal based feed at different proportion.

from plant and animal [23]. This result is similar to the report of several authors who have demonstrated the use of several species of duckweed as partial replacement for fishmeal in the diet of fish and other animals. Faskin et al. (2001) reported the use of duckweed Spirodella polyrrhiza in the diet of the Nile Tilapia (Oreochromis niloticus) [24]. Yilmaz et al. (2005) also observed no weight difference when $20 \%$ duckweed meal substituted for commercial fish meal in common carp (Cyprinous carpio). The growth depression that was observed at $30 \%$ fermented Lemna leaf meal incorporated in the diet of Labeo rohita gave the best performance in term of efficiency. The complete replacement of fish meal with duckweed is detrimental to fish production [25]. This is supported by the earlier workers [22, 23, 24] and Tavares et al. (2008) who have reported that $100 \%$ inclusion of duckweed does not favour growth performance of Nile Tilapia [26]. The study clearly showed that fish fed diet with $15 \%$ duckweed perform excellently well compared to other treatment. 


\section{Conclusion}

Fish nutritionists have tried since years to replace the expensive fish meal component of fish feeds with less expensive plant protein feed stuffs. For maximum growth of fish, optimum protein content in the feed is necessary. Generally, protein is recognized as a frequent limiting factor for growth of cultured fish. Studies pertaining to nutrition in freshwater aquaculture had resulted in the development of new feed formulations for carps. The experiment concludes that fish meal could not be replaced totally with plant origin feed; however, partial replacement can be done by using duckweed meal to reduce the cost without affecting growth rate. The present study revealed that $15 \%$ Lemna feed would be optimum for the maximum growth of Cyprinus carpio (L.). Further, such aquatic weed based feeds are cheaper as compared to the conventional feeds, supplementation of aquatic weeds in carp diets would also prove economically viable.

\section{Acknowledgements}

We are grateful to the Head, P.G.Department of Zoology, Utkal University, Bhubaneshwar for providing Library and laboratory facilities and the Head, Department of Zoology, Banki Autonomous College, Banki, Cuttack, Odisha for utilizing the laboratory set up to carry out the research work.

\section{References}

[1] Devaraj, K.V., G.Y. Keshavappa and J.K. Manissery, 1976. Growth of grass carp, Ctenopharyngodon idella fed on two terrestrial fodder plants. Aquaculture and Fisheries Management, 17:123-128.

[2] Jhingran, V.G., 1991. Fish and Fisheries of India. $3^{\text {rd }}$ Ed., Hindustan Publishing Co., Delhi, India.

[3] Shabbier, S., M. Salim and M. Rashid, 2003. Study on the feed conversion ratio (FCR) in major carp Cirrhinus mrigala fed on sunflower meal, wheat bran and maize gluten 30\%. Pakistan Vet. J., 23(1): 1-3.

[4] Inayat, L. and M. Salim, 2005. Feed conversion ratio ofmajor carp, Cirrhinus mrigala, fingerlings fed on soybean meal, maize gluten and maize. PakistanVet. J., 25(1): 13-17.

[5] Gull, Y., M. Salim, K. Shahzad and U.Noreen, 2005. Study on the growth performance and feed conversion ratio of Labeo rohita fed on soybean meal, blood meal and corn gluten 60\%. Indus J. Biol. Sci., 2(4):556-562.

[6] Woynarovich, A.; Bueno, P. B.; Altan, Ö.; Jeney, Zs.; Reantaso, M.; Xinhua, Y. andVan Anrooy R.2011. Better Management Practices for Carp Production in entral and Eastern Europe, theCaucasus and Central Asia. FAO Fisheriesand Aquacult. Tech. Paper. No 566. Ankara, FAO. 2011.153 pp.

[7] Edward, P., Kamal, M. and Wee, K.L. 1985. Incorporation of composted and dried water hyacinth in pelleted feed for the tilapia Orechromis niloticus (Peters). Aquaculture and Fisheries Management, 1:233-248. doi:10.1111/j.1365-2109.1985.tb00312.x

[8] Patra, B.C., \& Ray, A.K. 1988. A preliminary study on the utilization of the aquatic weed Hydrilla Verticillata (L.f.) Rayle as feed by the carp, Labeo rohita (Hamilton): growth and certain biochemical composition of flesh. Indian Biology. XX(I), 44-50.

[9] Ray, A.K. and Das, I.1995. Evaluation of dried aquatic weed, Pistia stratiotes meal as feedstuff in pelleted fed for rohu, Labeo rohita finferlings. Journal of Applied Aquaculture, 5:35-44.

[10] Wee,K.L. and Wany,S.S. 1987 Nutritive value of Leucaena leaf meal in pelleted feed for Nile Tilapia.Aquaculture,62,97-108

[11] Ahamad, M.U.; Swapon, M.R.S. Yeasmin, TU; Raham, M.S. and Ali, M.S. (2003) Replacement of sesame oil cake by Duckweed (Lemna minor) in broiler diet. Pakistan Journal of Biological Science 6(16) 1450-1453.

[12] Leonard, V 1995 Are aquatic plants particularly Azolla a useful source of food fish. In: (J.J. Symoens and J.C. Micha, eds). The management of Integrated Freshwater agro - Piscicultural Ecosystems in Tropical Areas. Proceedings Royal Academy of Overseas Science. Brussels, Belgium. Pp. $511-529$.

[13] Hassan, M.S. and Edwards, P. 1992. Evaluation of Duckweed (Lemna perpusilla and spirodella Polyrrhiza) as feed for Nile Tilapia (Oreochromis niloticus). Aquaculture. 104:315 - 326.

[14] Robinnette, H.R; Brunson, M.W. and Day, E.J 1980. Use of Duckweed in diets of channel cat fish. Mississippi Agricultural Experiment station. Publication No. 4532 Mississippi State University Mississippi State 13pp.

[15] Hanczakowski, P; Szymczyk, B and Wawizynski, M. 1995. Animal Feed Science and Technology. Institute of Animal Production. Balice, Poland. 53:3-4 Pp 339- 343.

[16] Americcan Public Health Association(APHA),1985

[17] Duncan, D.B. 1955. Multiple range and multiple F-tests.Biometrics, 11: 1-42.

[18] Jackson AJ, Capper BS, Matty AJ, 1982. Evaluation of some plant proteins in compound diets for the tilapia Sarotherodon mossambicus. Aquaculture, 27:97-109.

[19] Devaraj KV, Keshavappa GY, Manissery JK, 1986. Growth of grass carp, Ctenopharyngodon idella (Val.) fed on two terrestrial fodder plants. Aquaculture Fisheries Management, 17:123-128.

[20] Luo Z, Liu YJ, Mai K, Tian LX, Liu DH, Tan XY, 2004. Optimal dietary protein requirement of grouper Epinephelus coioides juveniles fed isoenergetic diets in floating net cages. Aquaculture Nutrition, 10:247-252.

[21] Deng J, Mai K, Ai Q, Zhang W, Wang X, Xu W, et al., 2006. Effects of replacing fish meal with soy protein concentrate on feed intake and growth of juvenile Japanese flounder, Paralichthys olivaceus. Aquaculture, 258:503-513.

[22] Sa R, Pousao-Ferreira P, Oliva-Teles A, 2006. Effect of dietary protein and lipid levels on growth and feed utilization of White Sea bream (Diplodus sarus) juveniles. Aquaculture Nutrition, 12:310-321.

[23] Das KM, Mohanty SN, Sarkar S, 1991. Optimum dietary protein to energy ratio for Labeo rohita fingerlings. In Proceedings of the Fourth Asian Fisheries Society, Spec. Publ., 5:205.

[24] Fasakin, E.A.; Balogun, A.M. and Fagbenro, O.A. (2001) Evaluation of sun dried water fern Azolla Africana and duckweed, Spirodella polyrrhiza, in practical diets for Nile Tilapia, Orechromis niloticus fingerlings. Journal of Applied Aquaculture. Vol II(4): 83-92.

[25] Yilmaz, E., A. Şahin, M. Duru and I. Akyurt. 2005. The effect of varying dietary energy on growth and feeding behaviour of common carp, Cyprinus carpio, under experimental conditions. Appl. Ani. Behav. Sci., 92 (1-2): 85-92.

[26] Tavares,F.A., J.Bosco,R.Rodrigues,D.M.Fracalossi,J.Esquivel and R.Rouback. 2008. Dried duckweed and commercial feed promote adequate growth performance of Tilapia fingerlings. Biotemas,21(3):91-97. 